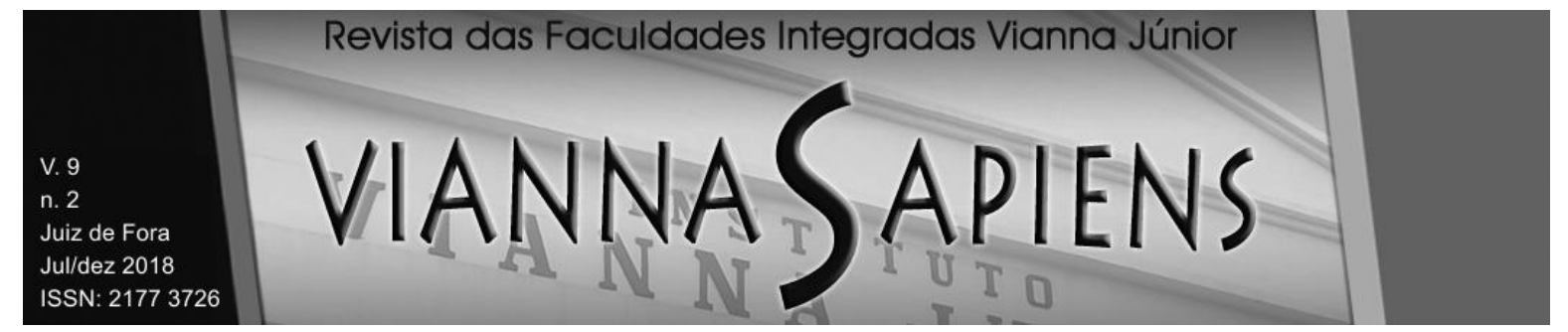

\title{
A MEDIAÇÃO COMO MEIO PARA A RESOLUÇÃO DOS CONFLITOS E O PAPEL DO ADVOGADO
}

DOI: 10.31994/rvs.v9i2.429

\author{
Amanda Garcia de Oliveira ${ }^{1}$ \\ Izabela Maria de Souza Pinheiro² \\ Nathália Pereira Correa ${ }^{3}$ \\ Raphaella Neman de Novaes ${ }^{4}$ \\ Thais Loures Junqueira ${ }^{5}$
}

\section{RESUMO}

O presente trabalho tem como objetivo a apresentação da mediação como um meio adequado nas soluções de conflitos, bem como a imprescindibilidade de melhor preparação dos advogados para o fomento e a efetivação da mediação. Dessa maneira, foi realizada vasta pesquisa doutrinária e documental para a averiguação da gênese desse meio adequado de resolução de conflitos, além da análise da importância do bom desempenho do advogado para o sucesso desse método, sendo apresentadas diversas técnicas de mediação existentes, visando a evidenciar que, em cada caso, deverá ser analisado a melhor forma de pacificação. Assim, com esse artigo, espera-se demonstrar que a mediação é uma forma de pacificação

\footnotetext{
${ }^{1}$ Graduanda do $9^{\circ}$ período do curso de Direito pelas Faculdades Integradas Vianna Júnior. e-mail: amandagoliveira27@gmail.com. Número do registro no orcid: 0000-0002-3128-3096.

${ }^{2}$ Graduanda do $9^{\circ}$ período do curso de Direito pelas Faculdades Integradas Vianna Júnior. e-mail: izabelapinheiro25@gmail.com. Número do registro no orcid: 0000-0002-5907-4405.

3 Graduada do curso de Direito pelas Faculdades Integradas Vianna Júnior. e-mail: nathaliapereirac32@gmail.com. Número do registro no orcid: 0000-0002-1315-1874.

${ }^{4}$ Graduanda do $9^{\circ}$ período do curso de Direito pelas Faculdades Integradas Vianna Júnior. e-mail: raphaneman@gmail.com. Número do registro no orcid: 0000-0001-7863-1716.

5 Graduada do curso de Direito pelas Faculdades Integradas Vianna Júnior. e-mail: thaisjunqueira@id.uff.br. Número do registro no orcid: 0000-0002-7050-0807.
} 


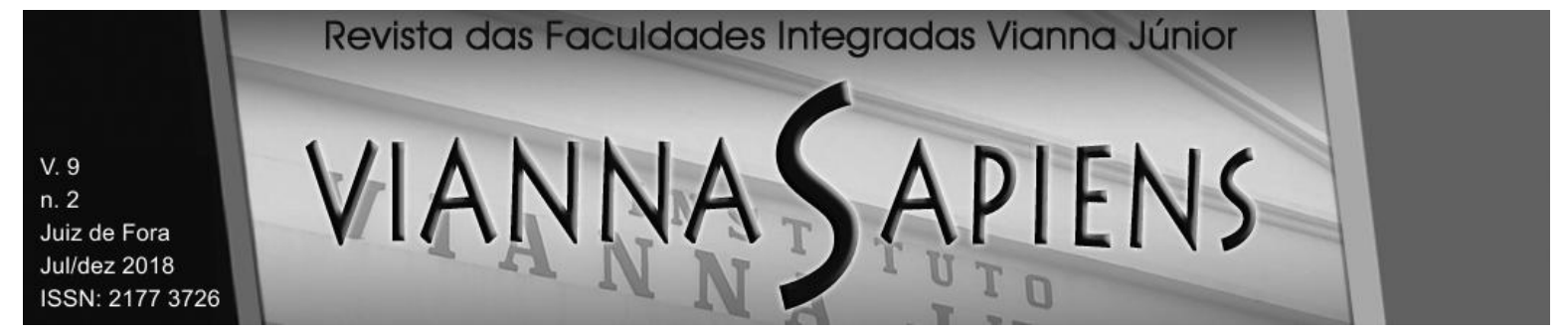

social, que foi incorporada no Brasil tardiamente, necessitando, portanto, de incentivo dos advogados e dos membros do poder judiciário para sua promoção. No mais, pretende-se atentar para a necessária mudança de paradigma na atuação jurídica atual, com vista à promoção da justiça de maneira célere e eficaz, utilizando, sempre que possível, a mediação para a solução de conflitos, devido aos seus inúmeros proventos.

PALAVRAS-CHAVE: MEDIAÇÃO. TRIBUNAL MULTIPORTAS. ADVOGADO MEDIADOR.

\title{
MEDIATION AS A MEANS FOR THE RESOLUTION OF CONFLICTS AND THE ROLE OF THE LAWYER
}

\begin{abstract}
The present work has the objective of presenting mediation as an adequate means in the solutions of conflicts, as well as the indispensability of better preparation of the lawyers to foment and carry out the mediation. In this way, extensive doctrinal and documentary research was carried out to investigate the genesis of this adequate means of conflict resolution, as well as the analysis of the importance of good lawyer performance for the success of this method, being presented several existing mediation techniques, that in each case the best form of pacification should be analyzed. Thus, this article hopes to demonstrate that mediation is a form of social pacification, which was incorporated in Brazil belatedly, thus necessitating the encouragement of lawyers and members of the judiciary for their promotion. In addition, it is intended to attend to the necessary paradigm change in the current juridical action, with a view to the promotion of justice in a fast and efficient way,
\end{abstract}




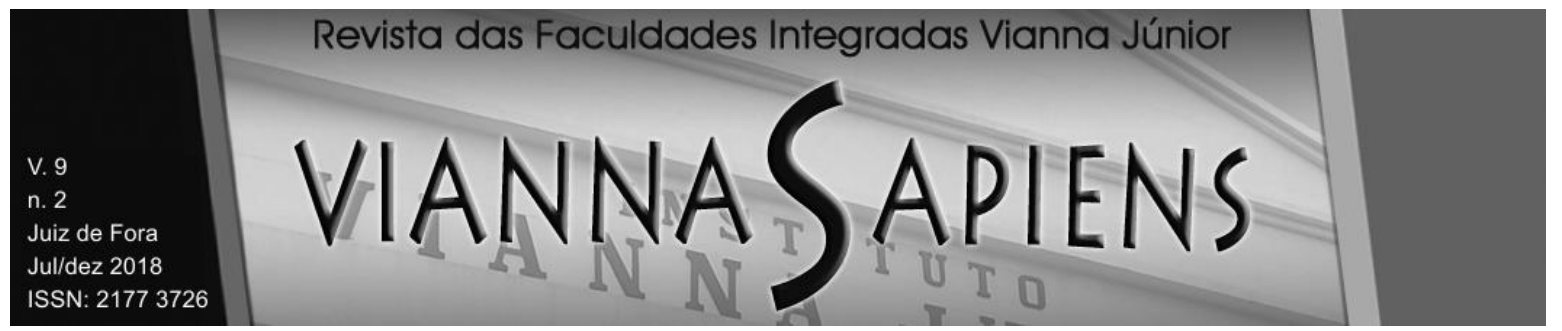

using, whenever possible, mediation for the solution of conflicts, due to its numerous benefits.

KEY-WORDS: Mediation. Multiport courts. Lawyer mediator.

\section{INTRODUÇÃO}

O artigo que se desenvolverá visa à apresentação da mediação como um meio adequado de resolução de conflitos, tendo em vista o novo Código de Processo Civil (Lei no 13.105/2015) e a promulgação da Lei de Mediação (Lei no 13.140/2015). Logo, há a necessidade de maior preparação na atuação dos advogados, e, por isso, o presente estudo também tem como objetivo desenvolver sobre o desempenho do advogado na mediação.

Para o desdobramento deste trabalho, fez-se uma pesquisa bibliográfica e documental sobre o tema, a fim de se buscar como foi instituído tal método de resolução de conflito no ordenamento jurídico brasileiro e como se dá o seu processamento. Além disso, há o intuito de entender a atuação necessária que o advogado necessita ter na mediação, seja como assessores legais das partes ou como mediador.

Com o intento de promover uma melhor compreensão do tema, dividiu-se o trabalho em três itens. No primeiro capítulo, foi feita uma abordagem do histórico legislativo até o atual cenário do ordenamento jurídico brasileiro, com o novo Código de Processo Civil e a Lei de Mediação.

O segundo capítulo desenvolve uma análise sobre a cultura do litígio no Brasil e o direito fundamental de acesso à justiça, previsto na Constituição Federal de 1988. Desse modo, discute-se a busca por procedimentos mais acessíveis, simples e adequados, que tragam maior efetividade e eficiência na resolução de conflitos, o que se desperta por meio da mediação. Por conseguinte, é apresentado como ela acontece. 


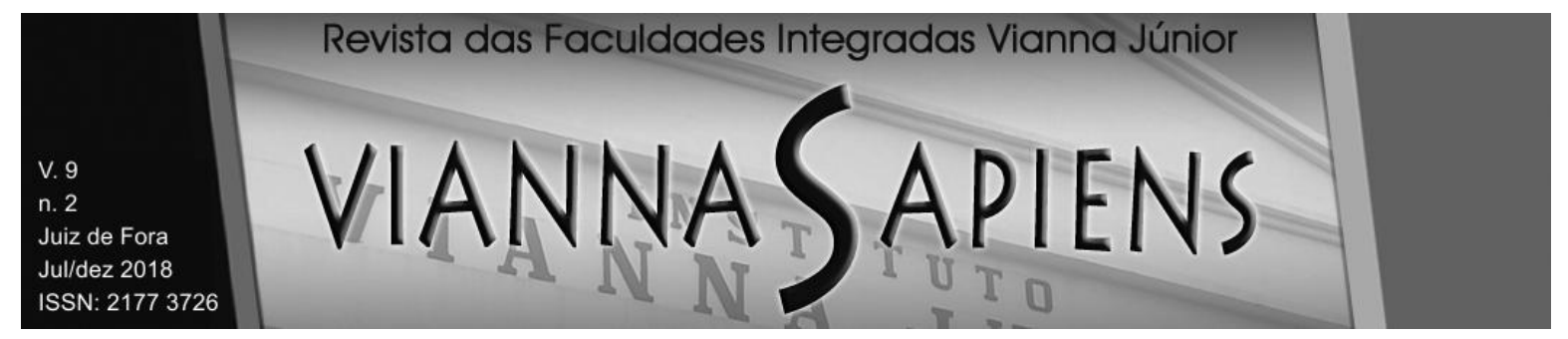

O capítulo final indaga a atuação do advogado na mediação, sendo ele um auxiliar legal das partes ou como mediador. Diante disso, é discutido acerca da legitimidade e dos requisitos necessários para ser mediador. Além disso, discute-se sobre os impedimentos e as restrições do advogado mediador, previstos na Lei de Mediação, bem como nos manuais e nas normas do Conselho Federal da OAB e do Conselho Nacional de Justiça (CNJ).

Com o presente trabalho, pretende-se concluir que há uma mudança de paradigma de extrema importância social, visto que a justiça brasileira demanda, cada vez mais, pelos métodos adequados de resolução de conflitos, como a mediação, bastando ver seus incontáveis benefícios para as partes envolvidas em um conflito.

\section{HISTÓRICO DA LEGISLAÇÃO}

A mediação pode ser considerada um meio adequado de solução de conflitos, por meio do qual um terceiro imparcial atua sem poderes decisórios, de forma a auxiliar as partes na resolução de suas controvérsias. É, dessa forma, uma maneira mais próxima de se atingir o acesso à justiça de forma justa, célere e eficaz.

Isso ocorre, pois o princípio da inafastabilidade da jurisdição (art.5ำ, XXXV da Constituição Federal/1988) encontra alguns bloqueios para ser exercido de forma plena. Entre eles, Cappelletti e Garth citam o alto custo do ingresso nas vias judiciais, a excessiva demora para a resolução do litígio e o formalismo intenso dos métodos judiciais (CAPPELLETTI e GARTH, 2002).

Nesse contexto, é que a mediação começou a se desenvolver, na esperança de encontrar novos métodos que solucionassem as controvérsias de forma mais efetiva, menos onerosa e mais satisfatória para ambas as partes envolvidas.

Pontual, foi a fala do Ministro Gilmar Mendes, na época Presidente do Supremo Tribunal Federal (STF), em seu discurso de posse: "[...] há necessidade de se debelar a cultura 'judicialista' que se estabeleceu fortemente no País, segundo a 


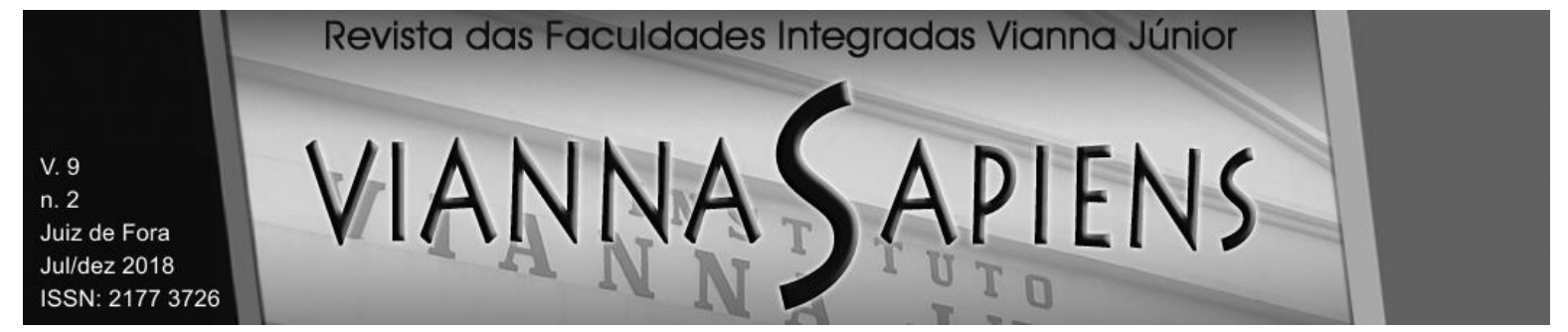

qual todas as questões precisam passar pelo crivo do Judiciário para serem resolvidas $[\ldots] "$.

Seguindo essa linha de pensamento, ficou nítido que havia necessidade social e judiciária de dar maior credibilidade e incentivar cada vez mais a utilização da mediação como forma de composição de conflitos. Já que a busca pelo judiciário extremamente formalizado não é nada eficaz e célere.

Foi nesse cenário de busca pela pacificação social que, no Brasil, nos anos de 1990, o interesse pela mediação materializou-se com o Projeto de Lei n4.827/1998, proposto pela deputada Zulaiê Cobra. Tal Projeto de Lei, encaminhado, a priori, à Câmara dos Deputados, tinha como principal escopo a regulamentação do instituto da mediação no País. Assim, a iniciativa descrevia e dispunha sobre aspectos outrora controvertidos no âmbito jurídico. Neste diapasão, Luis Felipe Salomão, atual Ministro do Superior Tribunal de Justiça (STJ), em "O marco regulatório para a mediação no Brasil" (SALOMÃO, 2015), alegou que:

a primeira tentativa de encaminhar uma lei versando especificamente sobre a mediação foi apresentada em 1998 (PL 4.827/98), definindo o instituto como "a atividade técnica exercida por terceira pessoa, que escolhida ou aceita pelas partes interessadas, as escuta e orienta com o propósito de Ihes permitir que, de modo consensual, previnam ou solucionem conflitos" (art. 1ํㅡㄹ caput), passível de ser utilizado antes ou no curso do processo judicial (art. $3^{\circ}$ ). O texto traz a possibilidade de homologação judicial do acordo obtido (art. $5^{\circ}$ ), a interrupção da prescrição e o impeço à decadência nas hipóteses em que o interessado requerer ao juízo a intimação da parte contrária para comparecer em audiência (art. 6으. . A proposta teve por objetivo fixar as diretrizes fundamentais do procedimento, sem regulamentar todas as suas minúcias. Aprovado o projeto na Câmara dos Deputados, a proposição seguiu para o Senado Federal (PLC 94/2002)

Conforme exposto, o Projeto de Lei supracitado, após ser aprovado na Câmara dos Deputados foi enviado ao Senado Federal, recebendo o no PLC 94/2002. No entanto, o texto inicialmente aprovado na primeira casa sofreu diversas modificações. Isso ocorreu por uma série de fatores externos, dentre os quais pode- 


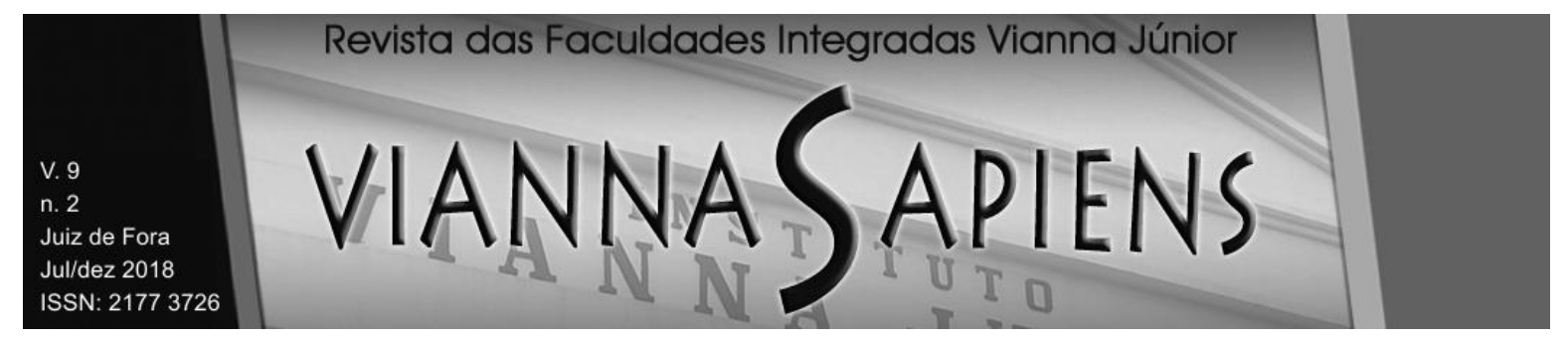

se citar a apresentação, pelo Governo Federal, de alguns projetos de lei objetivando a alteração do Código de Processo Civil, que culminou em um novo parecer sobre o Projeto de Lei que se encontrava no Senado Federal.

Além disso, vale salientar que houve a elaboração de um anteprojeto de lei sobre a mediação no Brasil, em que renomados juristas que compunham a Associação de Magistrados Brasileiros (AMB) e o Instituto Brasileiro de Direito Processual (IBDP) alertaram sobre alguns pontos do Projeto aprovado na Câmara dos Deputados.

Destarte, em meio a esse movimento de grande valia para o ordenamento jurídico brasileiro, o Ministério da Justiça promoveu uma audiência pública no dia 17 de setembro de 2003, a qual ocasionou um alinhamento do Projeto de Lei inicial com o anteprojeto apresentado, obtendo um único texto, enviado ao Senado Federal.

Acolhida a nova redação do Projeto de Lei pela Comissão de Constituição e Justiça do Senado e, após algumas modificações no texto original, ela foi levada à Câmara dos Deputados em 2006. Todavia, a proposta não prosseguiu na casa inicial, uma vez que não houve movimentações posteriores, de modo a gerar o arquivamento do projeto e a afastar a ânsia por um marco legal da mediação. (HALE; PINHO; CABRAL, 2016).

Isto posto, ficou nítido que, ao mesmo tempo em que havia um avanço, ainda seria necessário muito esforço e união para que uma regulamentação fosse concretizada. Nessa trilha, o Conselho Nacional de Justiça (CNJ) editou a resolução no 125 em 2010. De acordo com a resolução aludida, o instituto da mediação passou a ser descrito legalmente como uma forma adequada de composição dos litígios, que deveria ser fomentada pelo Poder Judiciário como um todo.

Cumpre salientar que todas as tentativas anteriores à resolução do $\mathrm{CNJ}$, incluindo-a, impulsionou a ânsia por mudança na legislação processual e também culminou em uma quebra de paradigma, em que não haveria o "ganhador" e o "perdedor" de um processo jurídico. Caminhava-se, portanto, para a regulamentação de um método real de acesso à justiça: a mediação. 


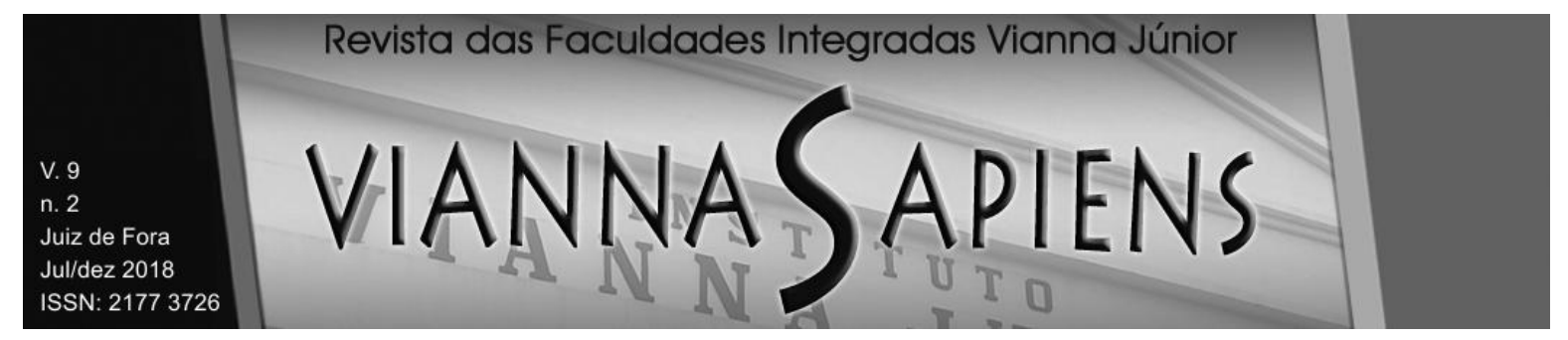

Visto isso, começou a existir uma mudança de postura dos operadores do direito, que passaram a aceitar melhor a ideia de uma celeridade na resolução de conflitos, o que culminou na publicação, em 2015, de um novo Código de Processo Civil (Lei no 13.105/2015) e de uma Lei da Mediação (Lei no⒔140/2015).

Ambas as leis publicadas em 2015 tratam dos meios autocompositivos de maneira acentuada, incentivando a utilização da mediação, bem como de outros métodos em que os advogados atuam de forma colaborativa e não adversarial. Pode-se dizer, portanto, que, após anos de tentativa de uma regulamentação da mediação, o marco legal ocorreu em 2015 com a publicação das leis supracitadas.

\subsection{A análise das Leis no $13.105 / 2015$ e no 13.140/2015}

As Lei 13.105/2015 e 13.140/2015, expostas previamente, contribuíram para uma quebra de paradigma, em que os princípios constitucionais e processuais são mais valorizados. Assim, é possível dizer que as leis foram pautadas, do início ao fim, na principiologia.

A exemplo disso pode-se citar o artigo $3^{\circ}$ do CPC/2015, no qual fica claro que o princípio da inafastabilidade da jurisdição, anteriormente apresentado, ganha uma nova roupagem, isto é, o acesso à justiça deixa de ser o acesso ao poder judiciário por si só e ganha um aspecto de direito ao ingresso pelo melhor método de composição, dentre os vários disponíveis. A respeito disso, a FGV Direito Rio (2012, p. 8) em "Tribunal Multiportas: Investindo no capital social para maximizar o sistema de solução de conflitos no Brasil”, afirmou que:

a jurisdição clássica, via Poder Judiciário, não é suficiente para os anseios da sociedade de riscos na busca pela justiça. Como saída, estão sendo realizadas inúmeras pesquisas no âmbito das soluções alternativas de conflitos, valendo destacar os trabalhos em curso no âmbito do Conselho Nacional de Justiça (CNJ) e da Associação dos Magistrados Brasileiros (AMB). Essas pesquisas têm ampla repercussão nacional no que se refere à implantação do sistema Multiportas, que permite a inclusão das minorias no processo de tomada de decisões com relação ao sistema de resolução de 


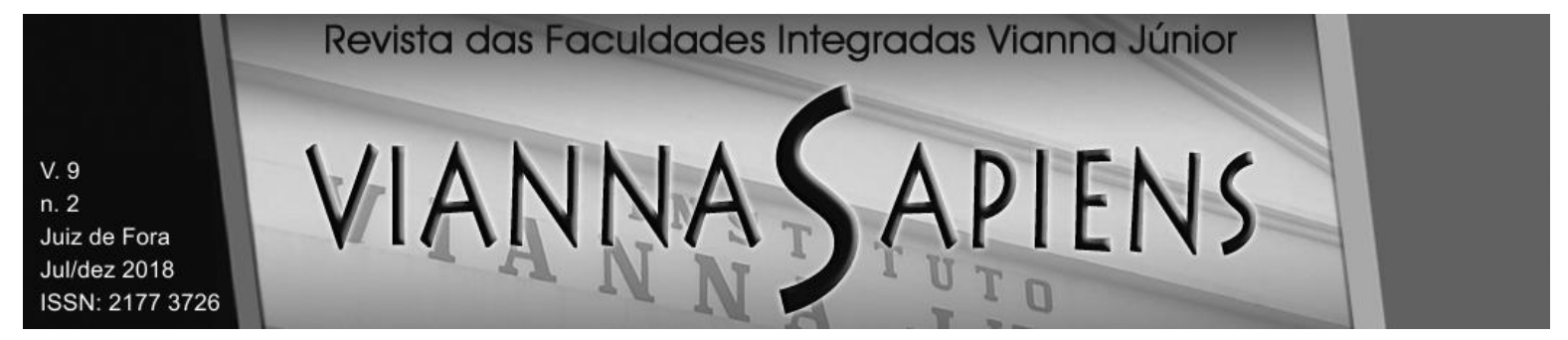

conflitos disponível, bem como o incremento do diálogo entre a sociedade civil e a comunidade jurídica.

A tal fenômeno, em que há vários meios de se solucionar um conflito e para cada caso concreto existe um mais adequado, é atribuído o nome de Tribunal Multiportas. Visto isso, nota-se que a regulamentação dos meios adequados de resolução de conflitos, com devido destaque à mediação, foi de extrema importância para uma tão aguardada mudança processual.

Outro fato a ser destacado, diz respeito à confidencialidade da mediação. Esse ponto, de extrema importância para as partes que são submetidas a esses processos autocompositivos, foi resguardado tanto pelo atual Código de Processo Civil (13.105/2015), em seu artigo 166, quanto pela própria Lei de Mediação (13.140/2015), em seu artigo 30.

Além dos aspectos legais já analisados, cumpre examinar a relevante questão do acesso à mediação pelas partes envolvidas. A tese é simples: a implementação da mediação teve como principal fator de concretização a facilidade do acesso à justiça, sendo regulamentada, nos artigos 165 (Lei 13.105/2015) e 24 (Lei 13.140/2015), que tratam da criação de centros judiciários de solução consensual de conflitos.

Seguindo essa linha de pensamento, na qual o legislador tentou incentivar ao máximo a autocomposição dos conflitos como tentativa de pacificação social, a questão da obrigatoriedade das audiências de mediação veio à tona. A dúvida sobre a obrigatoriedade da mediação surgiu com a leitura do caput do artigo 334 do atual Código de Processo Civil, em que o legislador afirmou que:

se a petição inicial preencher os requisitos essenciais e não for 0 caso de improcedência liminar do pedido, o juiz designará audiência de conciliação ou de mediação com antecedência mínima de 30 (trinta) dias, devendo ser citado o réu com pelo menos 20 (vinte) dias de antecedência 


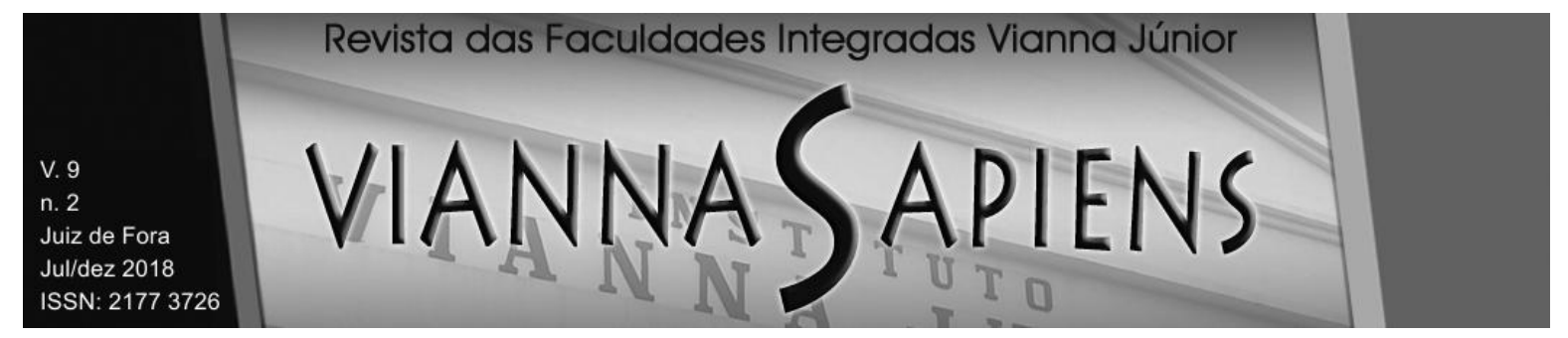

Assim, devido ao exposto no artigo supramencionado, houve uma certa incerteza de sua faculdade. No entanto, por mais relevantes que sejam esses métodos autocompositivos, o legislador deixou expresso no inciso I, §4ํㅡㄹ art. 334, CPC/2015, a possibilidade de não realização da mediação por vontade expressa de ambas as partes (autor e réu).

Dessa forma, ficou nítido que se uma das partes manifestar seu interesse na mediação, e não se tratar de casos em que não seja admitida a autocomposição (inciso II, (º $^{\circ}$, art. 334, CPC/2015), ela terá que ser realizada. Nesse diapasão, de grande incentivo à mediação, caso haja o não comparecimento injustificado de uma das partes na audiência, haverá incidência de multa ao ausente, de acordo com o $\S 8^{\circ}$, art. 334, CPC/2015.

Assim, tudo que foi retratado visou a uma mudança social e jurídica, a qual foi regulamentada por lei. Isso deve ser analisado como uma busca pela resolução de conflitos de forma mais efetiva, sem necessidade de provocar a jurisdição, de forma a garantir a ambas as partes a satisfação com os métodos autocompositivos.

\section{O QUE É E COMO ACONTECE A MEDIAÇÃO?}

No Brasil, o principal meio de resolução de conflitos é pelas vias judiciais. Litigar já virou costume na sociedade, a qual desenvolveu uma necessidade de procurar o Poder Judiciário para resolver os conflitos que, muitas vezes, deviam ser solucionados de forma extrajudicial.

Diante de tal situação, percebe-se o quanto a cultura brasileira de litigar e de ver o processo como uma solução para todos os problemas pessoais traz um resultado negativo para o Judiciário. Isso ocorre pois, com essas circunstâncias, há a quantidade excessiva de processos, a morosidade na resolução de mérito destes e o desgaste de anos e anos de uma demanda na Justiça para as partes, além de ocasionar custas processuais elevadas. 


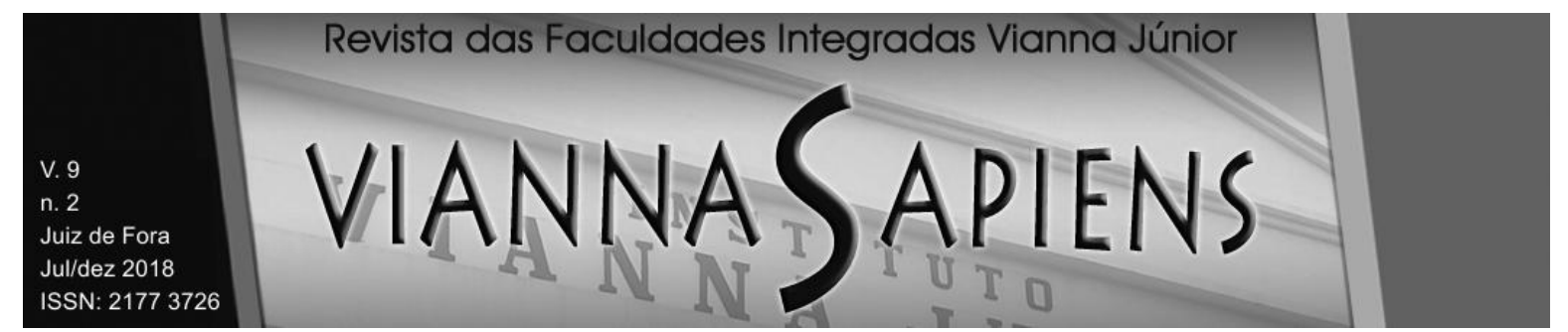

Cabe ressaltar o preceito fundamental garantido pela Constituição da República Federativa do Brasil (1988), previsto em seu art. 5ํ, XXXV e conceituado por Mauro Cappelletti (1988, p.8) como:

a expressão "acesso à Justiça" é reconhecidamente de difícil definição, mas serve para determinar duas finalidades básicas do sistema jurídico - o sistema pelo qual as pessoas podem reivindicar seus direitos e/ou resolver seus litígios sob os auspícios do Estado. Primeiro, o sistema deve ser igualmente acessível a todos; segundo, ele deve produzir resultados que sejam individual e socialmente justos.

Nesse ínterim, o princípio fundamental de acesso à justiça é uma garantia do ordenamento jurídico brasileiro à sociedade. Entretanto, devido ao acúmulo de litígios e à morosidade processual, esse princípio não é assegurado de forma efetiva e eficaz. Para modificar o paradigma atual de realização da Justiça, o ordenamento jurídico brasileiro está em busca de procedimentos mais acessíveis, simples e adequados, que tragam para a sociedade uma base de pensamento ganha-ganha, ao invés do modelo perde-ganha. Tais procedimentos estão representados, respectivamente, pelos métodos de resolução de conflitos autocompositivos e heterocompositivos.

Os métodos autocompositivos têm como perspectiva solucionar os conflitos através da vontade e atuação das partes, tendo, assim, um terceiro participante que será imparcial e interlocutor. Ressalta-se que as partes são as protagonistas nesse procedimento, e o terceiro imparcial é um condutor de diálogo. Esse procedimento é conhecido como mediação de conflitos.

Os métodos heterocompositivos, por sua vez, têm o enfoque de buscar a composição dos conflitos entre as partes pela intervenção de um terceiro participante, que será imparcial e atuante. Tais métodos são apresentados pela conciliação e pela arbitragem.

Contudo, como no presente trabalho o destaque é para a mediação, é interessante ressaltar suas atribuições e consequências. A mediação, então, é o 


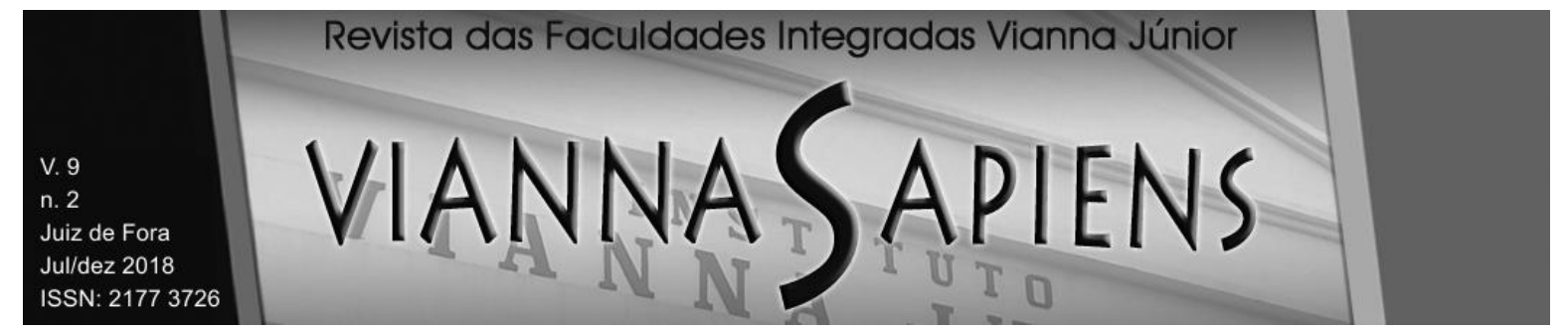

método de resolução de conflitos, no qual a busca pela composição é auxiliada por um terceiro com missão de conduzi-la. Esse terceiro interlocutor tem como objetivo neutralizar as emoções e a auxiliar na formação de ideias e na negociação dos acordos. Ademais, o foco principal desse processo não é apenas a simples composição do conflito por meio de um termo final, e, sim, atingir as questões emocionais mais profundas, que nem sempre são expressas, com o fim de solucioná-las.

Para isso, é pertinente discutir o conceito de conflito. Esse é analisado por diferentes ciências e apresenta diversas definições. Assim, segundo a teoria do conflito implementada por Max Weber (apud WEISS, 2014), o conflito é atribuidor de perdas para uma das partes e é colocado como um fenômeno negativo na sociedade, proporcionando o aumento de empates e litígios.

Em contrapartida, a teoria moderna do conflito vem com uma proposta sob um novo ponto de vista, o qual seria mais adequado e construtivo para a sociedade e seus indivíduos. Segundo essa teoria, o conflito traz oportunidades de aprendizado, crescimento, amadurecimento e perspectivas de admirar o surgimento das diferenças como uma possibilidade de enxergar o mundo de outra forma. Portanto, trata-se o conflito como um fenômeno positivo, evolutivo e natural para o convívio humano. Bem como a autora Mary Parker Follett (1997, p.298) defende:

o conflito é algo inerente às relações humanas e dele não podemos fugir, representa a diferença que habita a individualidade humana. Cada indivíduo tem propósitos, desejos e vontades pessoais que muitas vezes conflitam com os de outros. Devemos, assim, aproveitar a energia do atrito causado pela divergência de interesses, ideias e visões de mundo para construir novas realidades, novos relacionamentos, em patamares mais produtivos para todos os envolvidos no conflito. Pela Teoria Moderna do Conflito, uma opção válida para solução dos conflitos é afastar as abordagens dominadoras, comumente adotada, e excessivamente concessiva para adotar uma terceira forma, a integradora de interesses de forma construtiva 


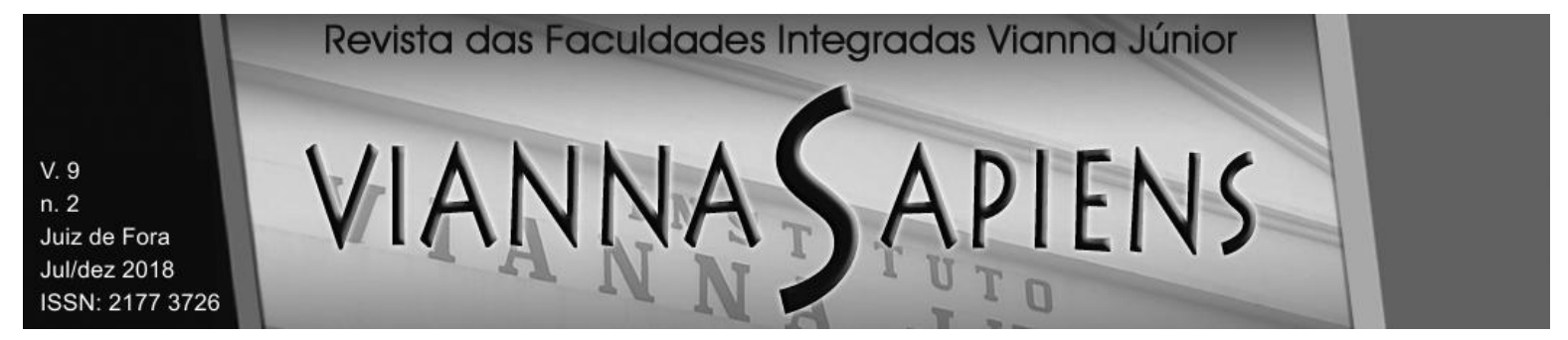

De acordo com esse prisma, o mediador deve identificar os valores, as origens culturais, as aspirações, os interesses e os objetivos de cada parte em conflito na mediação, os chamados mediandos, para que, com isso, seja possível articular meios de diálogo entre eles, e, por fim, solucionar as pendências nos aspectos subjetivos - sentimentais - e objetivos - os negociais.

Destarte, a mediação é um procedimento abrangente por solucionar tanto os aspectos sentimentais quanto os negociais. Mas, para proceder dessa forma, a mediação apresenta três modelos principais utilizados em países como Estados Unidos, Argentina e Uruguai, sendo eles: o Modelo de Harvard que é o tradicional, o Modelo Transformativo que foi desenvolvido por Bush e Folger, e o Modelo CircularNarrativo, formulado por Sara Cobb.

O Modelo de Harvard é articulado pela causalidade linear do conflito, ou seja, não leva em consideração o contexto em que o conflito foi produzido, tendo um sentido mais objetivo ao acordo. Consequentemente, não há uma preocupação com a relação entre as partes e nem com a transformação destas.

O Modelo Transformativo tem como base a causalidade circular do conflito, isto é, trabalha-se para o fim de desenvolver o potencial de mudanças nos mediandos. Com isso, há o foco na relação interpessoal, e parte-se de novos modelos comunicacionais, independente do processo de mediação alcançar um acordo final.

Por fim, o Modelo Circular-Narrativo une os dois modelos anteriores, focalizando tanto o conflito - relação entre mediandos - quanto o termo final - o acordo sobre questões objetivas. Logo, parte-se da ideia de que os indivíduos e o conflito não podem ser analisados de maneira isolada.

Vale salientar que não existe um modelo correto para se adotar a mediação. Cada mediador escolhe qual desses modelos é o mais adequado e que está em conformidade com a conduta adotada profissionalmente.

Ademais, a mediação pode ser feita por vias judiciais ou extrajudiciais. A mediação judicial passou a ser incentivada com o Novo Código de Processo Civil, Lei no 13.105/2015, o qual legitimou os meios adequados de resolução de conflitos. 


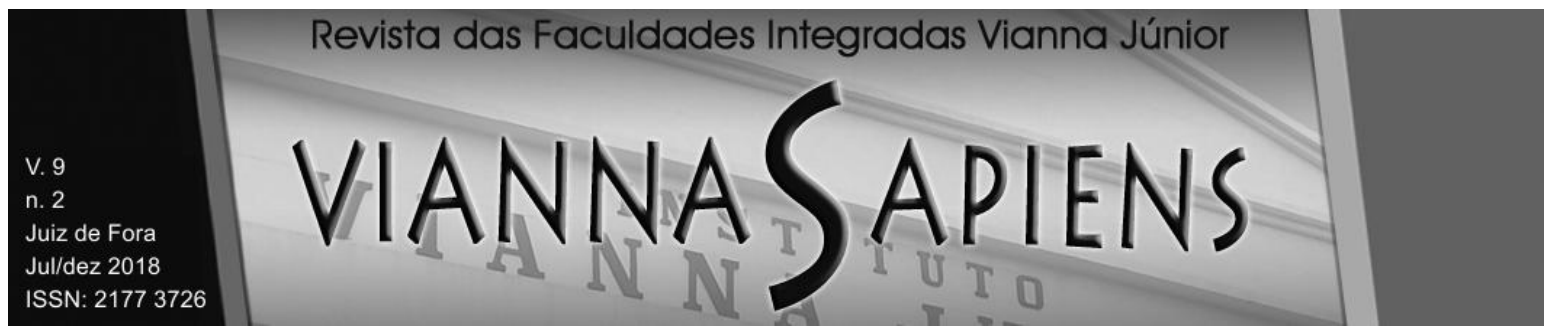

E a mediação extrajudicial, também chamada de mediação privada, ocorre fora do Judiciário e consiste em um caminho mais rápido e eficaz para resolução dos conflitos, além de ser um meio encontrado para aliviar o acúmulo processual.

Em muitos países a mediação privada já alcançou êxitos grandiosos, a exemplo dos Estados Unidos, Argentina, Canadá, Reino Unido e Uruguai. Para atingir esses resultados, são necessários no mínimo incentivos, sendo eles: (i) lei que estimule a formação do mercado privado da mediação; (ii) incentivo do Judiciário na formação do mercado privado; e (iii), nos setores empresariais, buscar uma maneira eficaz e confiável de solucionar problemas e ainda manter as relações comerciais, ou seja, prever a mediação como método de resolução de conflito por meio de cláusula contratual.

Por conseguinte, a mediação no Brasil ainda é pouca praticada, embora seja muito discutida. Com o marco legal, instituído pela lei de oㅜ 13.140 de 26 de junho de 2015 e por meio de resoluções feitas pelo Conselho Nacional de Justiça (CNJ), aprimorara-se mais a discussão pela implementação da mediação como uma solução na crise do Judiciário. Ademais, relata-se que a realidade brasileira ainda está longe de se adequar totalmente a esse sistema, devido ao preconceito com relação a esse método de resolução de conflito pelos operadores da justiça, principalmente os advogados, os quais ainda estão presos à cultura da lide.

\section{O ADVOGADO NA MEDIAÇÃO}

\subsection{O advogado como mediador}

O advogado possui uma função imprescindível no processo judiciário, uma vez que ele é o detentor do jus postulandi na maior parte das situações, como também é fundamental "à administração da Justiça, é defensor do Estado democrático de direito, da cidadania, da moralidade pública, da Justiça e da paz 


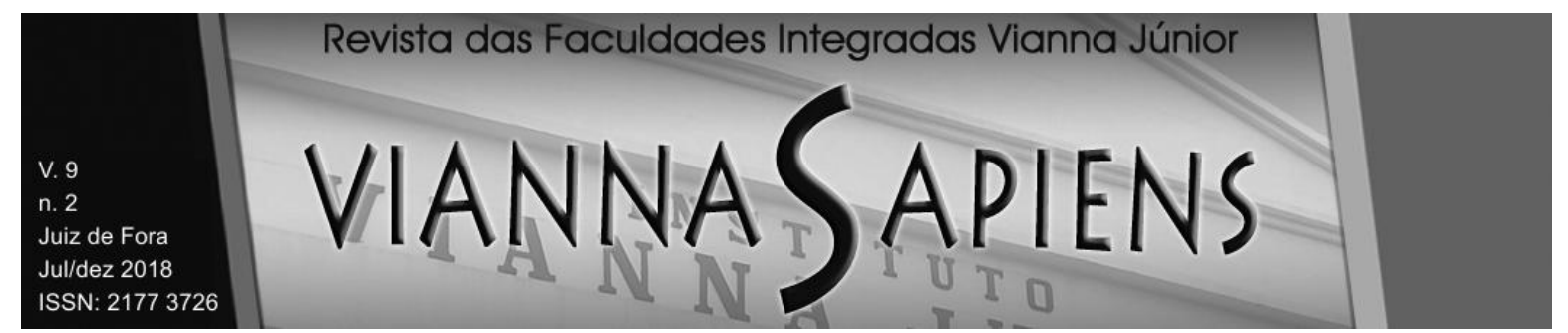

social" (CÓDIGO DE ÉTICA E DISCIPLINA, 1994). Nesse contexto, o advogado tem, de acordo com Louis J. Weber Junior (1993, p. 2116):

uma oportunidade única para prestar serviço ao público, bem como a liderança para a profissão através do movimento dos métodos adequados de solução de conflitos. Como mediadores, podemos nos tornar verdadeiros pacificadores sem sermos considerados ávidos. Podemos usar nosso treinamento legal e habilidades interpessoais para realmente ajudar a resolver as diferenças em vez de apenas ganhar casos. Estamos em um ponto crítico na profissão como vemos os métodos adequados de solução de conflitos cada vez mais popular; temos a obrigação de evitar a tentação de simplesmente ganhar dinheiro com uma mercadoria quente. Temos o potencial de afetar significativamente as atitudes das partes que disputam entre si da mentalidade "vencer a todo o custo" para a "solução ganha-ganha" pela qual as disputas são difundidas (tradução nossa)

A mediação não deve ser vista de uma forma pejorativa e nem ameaçadora à função básica do advogado, mas como uma outra maneira de resolução dos conflitos. Investidos da função de mediadores, os advogados podem utilizar diversas características, únicas de grupo, e aplicá-las à mediação. Ademais, o Código de Ética e Disciplina (1994) considera, no seu artigo $2^{\circ}$, inciso VI, um dever do advogado o estímulo à conciliação entre as partes para que não seja instaurado o litígio.

O autor Asdrubal Junior (2004) discorre em seu trabalho sobre o "perfil de caçador de soluções" que deve estar presente no advogado, norteando-o durante a mediação. Deixa-se, assim, a posição de "soldado beligerante", aquele que luta pela vitória ininterruptamente, mesmo que não solucione o conflito, para se tornar o "caçador de soluções".

Segundo o Manual de Mediação de Conflitos para Mediação (2014), desenvolvido pelo Conselho Federal da $\mathrm{OAB}$, são funções do advogado-mediador: focar nas questões principais em que se baseiam o conflito, analisar o caso, identificar os interesses de cada parte a fim de possibilitar um acordo.

Sobre a função de mediador, segundo o artigo 11 da Lei 13.140 (2015), ela pode ser exercida por pessoas que tenham se graduado em um curso de ensino 


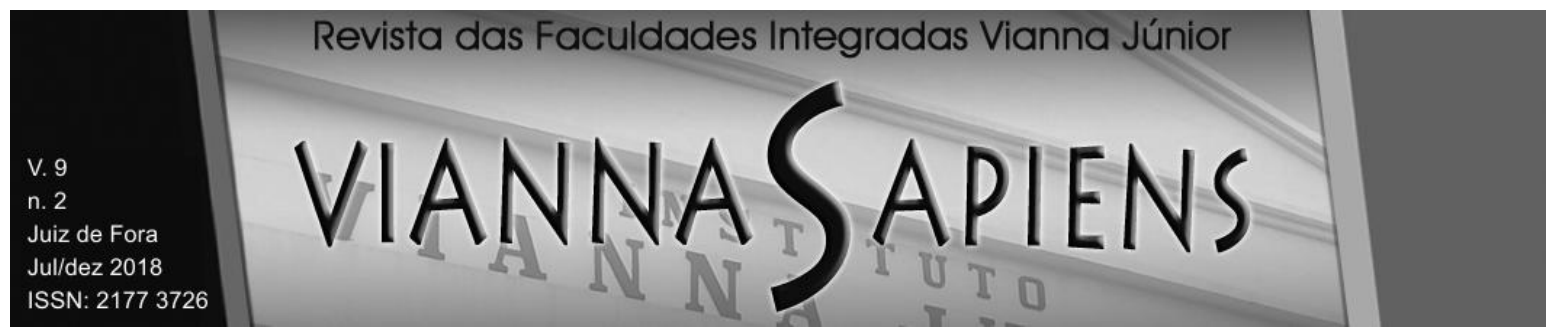

superior, há pelo menos dois anos, e que tenham realizado o curso de capacitação para mediadores, sendo este regulamentado pela Resolução 125 (2010) do Conselho Nacional de Justiça (CNJ).

\subsection{Restrições e impedimentos}

O advogado tem legitimidade para exercer o papel de mediador, contudo essa função pode gerar alguns impedimentos a esse profissional. O novo Código de Processo Civil (2015) estabelece, no artigo 167,§ 5, que "os conciliadores e mediadores judiciais cadastrados na forma do caput, se advogados, estarão impedidos de exercer a advocacia nos juízos em que desempenhem suas funções". Segundo Débora Pinho (2015), o novo código privilegia e estimula os procedimentos adequados de resolução de conflitos, contudo esse parágrafo geraria um obstáculo no desenvolvimento destes métodos, visto que o advogado terá que fazer uma escolha entre advogar ou mediar.

Ademais, Tadeu Rover (2015) discorre sobre os impedimentos, que, segundo o entendimento do Tribunal de Ética e Disciplina da Ordem dos Advogados do Brasil de São Paulo, o advogado, investido da função de mediador, não pode advogar para nenhum indivíduo que já atuou como mediador. Também, há o impedimento de desempenhar a função de advogado nas varas nas quais já mediou, de acordo com o Código de Processo Civil.

Outrossim, geraria uma desigualdade dentre advogados-mediadores e profissionais de outras áreas atuando como mediadores, pois estes não teriam restrições. Débora Pinto (2015) e Marcelo Mazzola (2015) defendem que essa norma não teria fundamento, uma vez que os mediadores não possuem familiaridade com os juízes, já que as mediações não são designadas pessoalmente e as sessões ocorrem em centros de mediação.

Outro argumento seria que o mediador tem 0 dever de declarar 0 impedimento ou suspeição, tal como o juiz, sendo possível a responsabilização administrativa e penal do mediador (MAZZOLA, 2015). Portanto, Marcelo Mazzola 


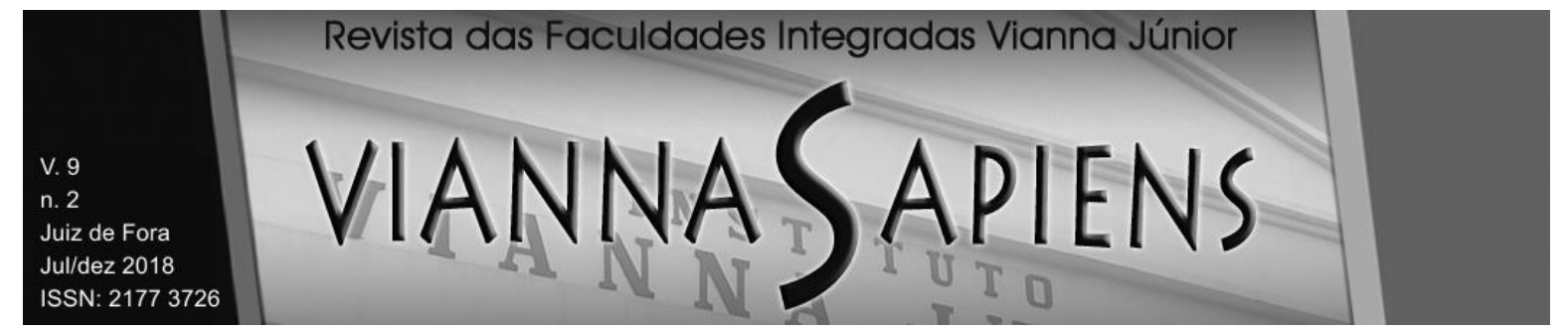

(2015) considera que os tribunais devem começar a flexibilizar essa restrição, de forma a entender também que o dispositivo sobre o impedimento de o mediador representar qualquer parte que já atuou como mediador seria válido e coerente com o Código de Processo Civil e a Lei oํ 13.140/15. Tal viés é, portanto, oposto às conclusões de Débora Pinto (2015), que acredita que o mediador e as partes não podem ser próximas, e defende a alteração ou a exclusão desses dispositivos, a fim de tornar viável a prática das duas funções (mediador e advogado) por um mesmo profissional.

\subsection{A atuação do advogado na mediação}

Segundo Tânia Almeida (2014), a mediação propõe uma mudança de paradigmas, tanto para as partes quanto para os advogados, iniciando pela pretensão das partes como autoras da solução, transferindo-Ihes a voz ao longo das sessões. Como diz a renomada autora, "senta-se à mesa quem tem poder decisório, representando a própria voz".

Outro fator importante que merece ser trabalhado no presente artigo é o papel do advogado na mediação. Diferentemente do que ocorre nos processos judiciais comuns, nos quais os advogados são defensores de seus clientes, na mediação eles são assessores legais das partes.

Nesse sentido, Tânia Almeida (2014) traz em seu artigo 'Mediação de Conflitos: Um meio de Prevenção e resolução de controvérsias em sintonia com a atualidade' que:

Os advogados podem ter extensa atuação na mediação. Além de oferecerem os parâmetros legais para os temas em negociação, podem, ainda, assessorar seus clientes:

1) na escolha do mediador, ao privilegiar o conhecimento na matéria ou na condução do processo de mediação;

2) na identificação de seus interesses e necessidades, clarificando a demanda;

3) no preparo para participar da mediação, ao informar sobre os princípios éticos, a dinâmica do processo e seus procedimentos; 


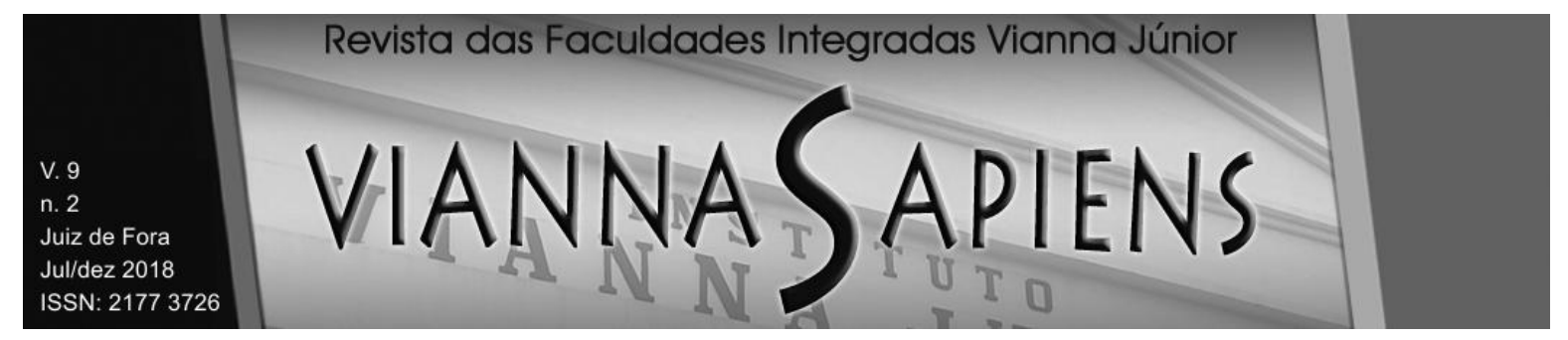

4) na identificação dos interesses e das necessidades da outra parte, de forma auxiliar a criar soluções de benefício mútuo.

\subsubsection{O advogado como assessor jurídico da parte}

A participação do advogado no processo de mediação pode ocorrer de diversas formas, conforme já explicitado, uma delas é a participação como assessor jurídico das partes.

Inicialmente, cumpre ressaltar que a participação do advogado nas sessões ou reuniões de mediação tem função acessória, ou seja, o advogado atua como assessor jurídico para auxiliar o cliente nas demandas necessárias, esclarecendo as questões de direito que demandem orientação.

Essa participação consultiva do advogado nas sessões de mediação pode ser justificada pelo princípio da oralidade, conforme trazido por Carlos Eduardo Vasconcelos (2014, p. 55):

a dialética da mediação é ditada pela oralidade da linguagem comum. As partes ou mediandos são os principais protagonistas do procedimento, mesmo quando contam com a assistência dos seus advogados.

A atuação do advogado poderá estar direcionada para duas vertentes distintas, sendo a primeira delas quando o profissional encontra-se em processos heterocompositivos e a segunda quando se encontra em processos autocompositivos. Porém, em ambas as situações os advogados terão os mesmos interesses, quais sejam: ter um bom desempenho, reconhecimento profissional, aumentar a gama de clientes, etc.

No presente artigo, estamos tratando da atuação do advogado em processos autocompositivos, nos quais são necessárias algumas mudanças de comportamento profissional.

Os principais fatores modificativos do comportamento dos advogados são as características da mediação, em função das quais há o estímulo de intercâmbio de 


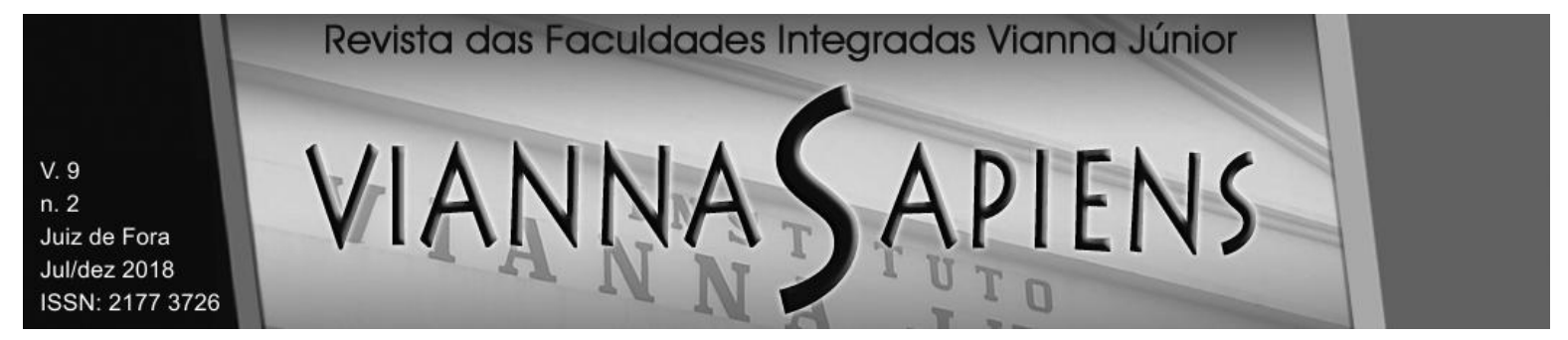

informações, valoriza-se o auxílio para a melhor compreensão das perspectivas das partes, há uma busca pela expressão dos interesses e dos sentimentos de forma clara, além da constante promoção do diálogo voltado para a melhoria do relacionamento das partes no futuro.

Destarte, é possível notar que a mediação não pode ser compreendida pelo advogado apenas sob uma dimensão jurídico-contenciosa, mas, sim, deverá existir o estímulo para a atuação com o intuito de compor a controvérsia de maneira criativa, de forma a incentivar seu cliente a entender as necessidades da parte contrária e praticar a empatia.

Embora não seja obrigatória a presença do advogado, uma vez que o diálogo não irá necessariamente tratar de questões jurídicas, é importante a participação do assessor jurídico para sanar as possíveis questões, podendo, inclusive, a sessão ser suspensa para a obtenção dos esclarecimentos necessários.

\subsubsection{O advogado como auxiliar na escolha do mediador.}

Além de assessorar a parte acerca da matéria tratada na mediação, o advogado também poderá atuar como assessor técnico, ou seja, ele pode auxiliar na escolha do mediador no âmbito privado (ALMEIDA, 2014).

Para a escolha do mediador e da técnica a ser utilizada, o advogado deverá conhecer as escolas de mediação e suas diferenças substanciais, visto que possuem procedimentos diversos e indicações para casos que versem sobre matérias diferentes.

\section{CONCLUSÃO}

Compulsando sobre mediação como uma forma adequada de solução de conflitos, bem como o papel do advogado nesse cenário, conclui-se, inicialmente, 


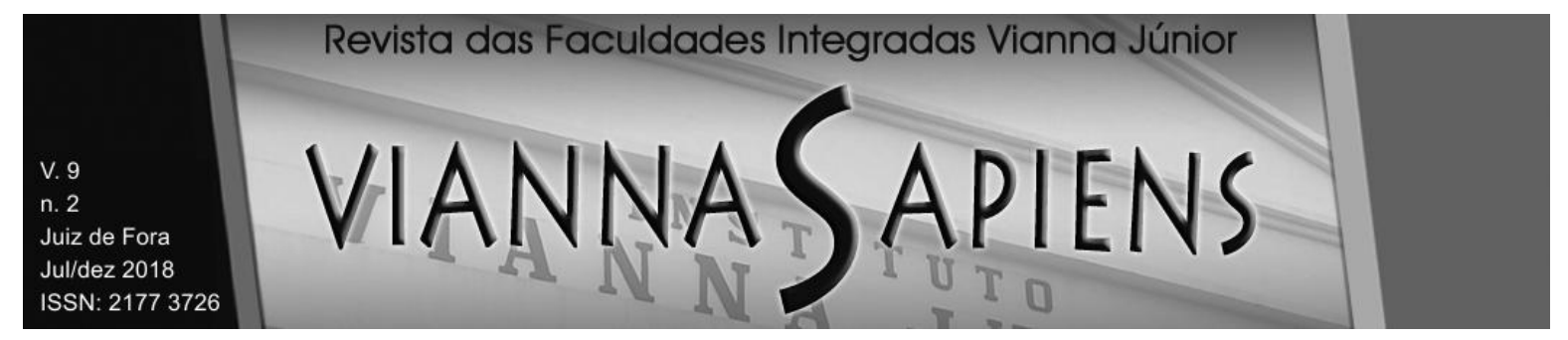

que a visão de que a justiça só é alcançada nos tribunais já está ultrapassada, vez que o dito Tribunal Multiportas é o que deve prevalecer na sociedade atual.

A mediação como uma forma de pacificação social foi tardiamente regulamentada no Brasil, ademais ainda encontra obstáculos para seu total aproveitamento. Assim, apesar da resistência que ainda existe na utilização da mediação como resolução do conflito, os advogados, enquanto profissionais primordiais ao acesso à justiça devem incentivá-la sempre que houver compatibilidade do litígio com esse método, a fim de buscar uma satisfação para o seu cliente de maneira mais eficaz e célere.

Depreende-se, ainda, a manifesta importância dos profissionais supracitados no que diz respeito à busca de melhores soluções para o cliente, de forma a afastar a antiga mentalidade de oposição nos tribunais. Não obstante ao que foi relatado, é necessário expor que, conjuntamente ao incentivo à mediação, deve existir um terceiro imparcial que atue de maneira passiva, mas que conduza de maneira positiva a composição do conflito.

Além disso, é de suma importância a análise dos modelos de mediação existentes, tais como o de Harvard, o Transformativo e o Circular- Narrativo, para a escolha do que for mais adequado ao conflito existente, bem como com o intuito de atingir uma real eficácia.

Ademais, ressalta-se a possibilidade de o advogado atuar como mediador, o que não é absoluto. Assim, são elencados, no Código de Processo Civil (2015), algumas restrições e impedimentos desta atuação, que tem por escopo a manutenção da imparcialidade na autocomposição.

Na medição, é preciso que o advogado da parte entenda que não irá atuar da mesma maneira que nos processos jurídicos. Tal fato corresponde a uma mudança de paradigma de extrema importância social, pois, neste último caso, o patrono atua como assessor jurídico do seu cliente, esclarecendo questões de direito e orientando-o. 


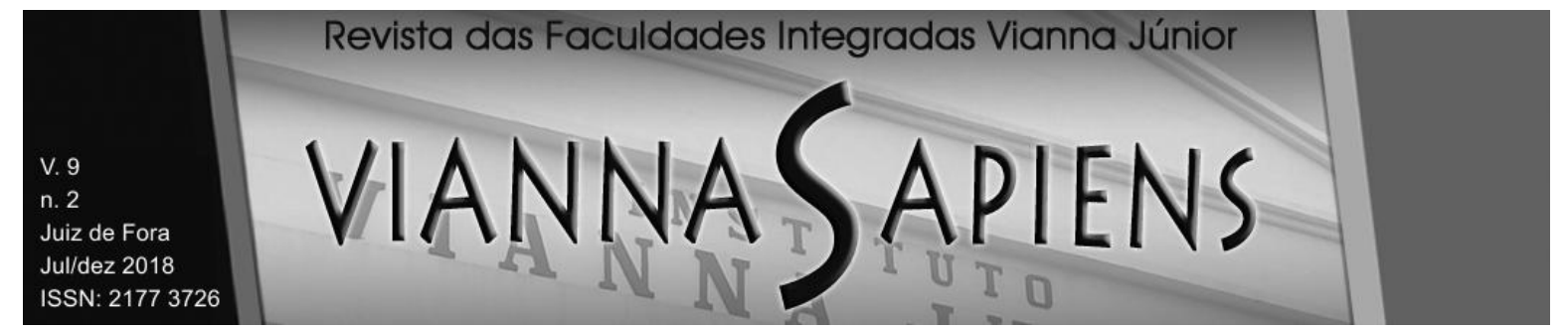

Vale salientar que o advogado da parte poderá, ainda, participar da mediação no sentido de ajudar na escolha do mediador, tendo em vista a diversidade de modelos existentes, como citado anteriormente.

Assim, conclui-se com o presente artigo, que há uma necessidade de mudança na mentalidade de todos os membros do Poder Judiciário, para que haja estímulo à mediação, tendo em vista seus incontáveis e já citados benefícios para as partes que litigam.

No atual contexto social, deve-se primar pelo diálogo para a resolução de conflitos entre indivíduos e despir-se dos preconceitos sobre as novas formas de composição, tais como a mediação, destaque do presente trabalho. Com isso, será possível auxiliar na evolução da justiça brasileira.

\section{REFERÊNCIAS}

ALMEIDA, Rafael Alves de; ALMEIDA, Tania; CRESPO, Mariana Hernandez. Tribunal Multiportas: investindo no capital social para maximizar o sistema de solução de conflitos no Brasil. Rio de Janeiro: Editora FGV, 2012.

ALMEIDA, Tania. Caixa de ferramentas em mediação: aportes práticos e teóricos. São Paulo: Dash, 2014.

ASDRUBAL JUNIOR. O Advogado na Mediação e na Arbitragem. In: Âmbito Jurídico, Rio Grande, VII, n. 16, fev 2004. Disponível em: <http://www.ambitojuridico.com.br/site/index.php?n_link=revista_artigos_leitura\&artigo_id=3330 >. Acesso em: 20 fev. 2017.

BRASIL. Constituição (1988). Constituição da República Federativa do Brasil. Brasília: DF: Senado, 1988. 


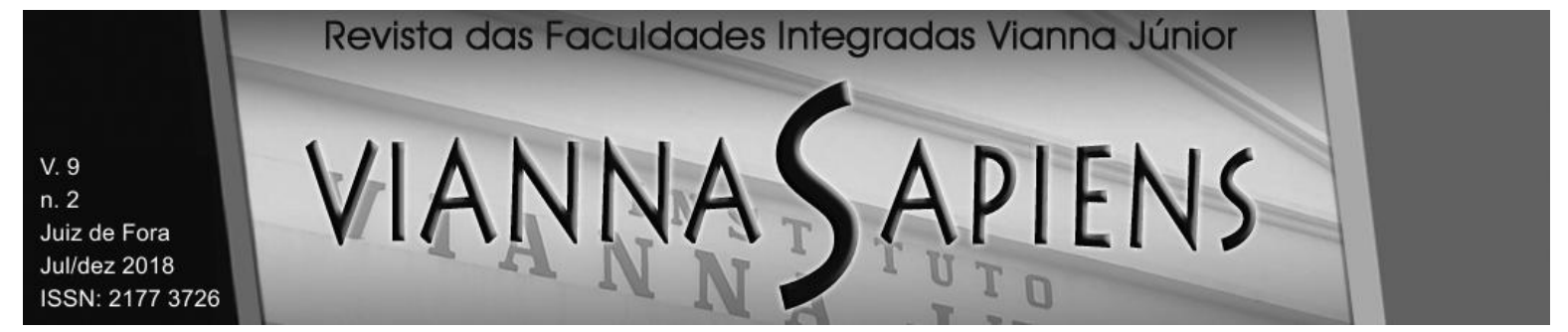

BRASIL. Lei n 13.105 de 16 de março de 2015. Código de Processo Civil. Congresso Nacional. Disponível em:

<http://www.planalto.gov.br/ccivil_03/_ato2015-2018/2015/lei//13105.htm>. Acesso em: 23 fev. 2017.

BRASIL. Lei $n^{\circ}$ 13.140. Dispõe sobre a mediação entre particulares como meio de solução de controvérsias e sobre a autocomposição de conflitos no âmbito da administração pública; altera a Lei no 9.469, de 10 de julho de 1997, e o Decreto no 70.235, de 6 de março de 1972; e revoga o § 20 do art. 60 da Lei no 9.469, de 10 de julho de 1997. 2015. Disponível em:

<http://www.planalto.gov.br/ccivil_03/_ato2015-2018/2015/Lei/L13140.htm>. Acesso em 27 fev. 2017.

CAPPELLETTI, Mauro. Acesso à Justiça. Tradução de Ellen Gracie Northfleet. Porto Alegre: Fabris, 1988.

CAPPELLETTI, Mauro; GARTH, Bryant. Acesso à justiça. Porto Alegre: Sérgio Antônio Fabris Editor, 2002.

CONSELHO FEDERAL DA ORDEM DOS ADVOGADOS DO BRASIL. Código de ética e disciplina da OAB. Brasília: 1995. Disponível em:

$<$ https://www.oabes.org.br/arquivos/CodEticaDisciplinaOAB.pdf>. Acesso em: 27 fev. 2017.

CONSELHO NACIONAL DE JUSTIÇA. Resolução n 125. Dispõe sobre a Política Judiciária Nacional de tratamento adequado dos conflitos de interesses no âmbito do Poder Judiciário e dá outras providências. 2010. Disponível em: <http://s.conjur.com.br/dl/resolucao-1252010-conselho-nacional.pdf>. Acesso em: 27 fev. 2017.

FERREIRA, Lúcia da Costa. Teorias de Conflito. São Paulo, 2014.

Disponível:<http://pt.slideshare.net/JorgeLuizVSantos/teoria-do-conflito>. Acesso em 10.Fev.2017.

FOLLETT, Mary Parker. Mary Parker: profeta do gerenciamento. Tradução de Eliana Hiocheti e Maria Luiza de Abreu Lima. Rio de Janeiro: Qualitymark, 1997, p.298. 


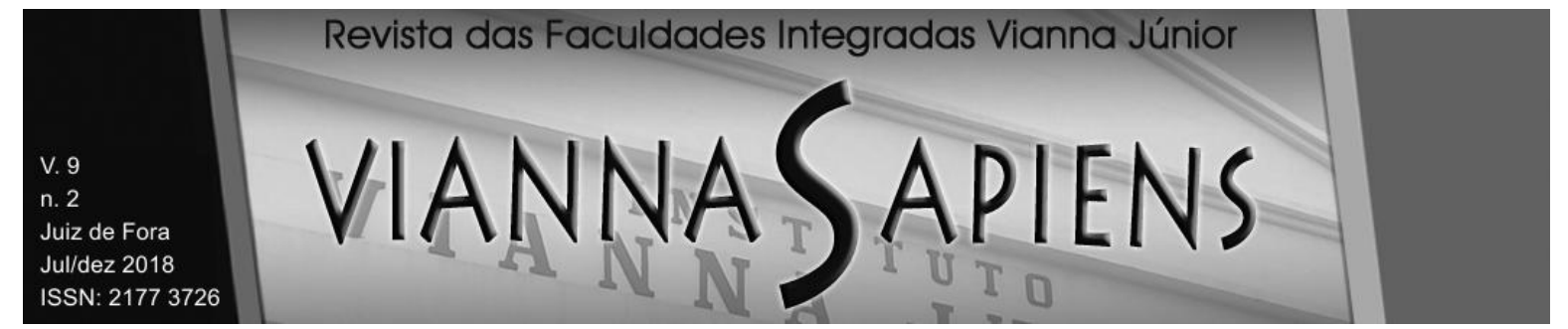

HALE, Durval; PINHO, Humberto Dalla Bernardina; CABRAL, Trícia Navarro Xavier. O marco legal da mediação no Brasil: comentários à lei no 13.140, de 26 junho de 2015. São Paulo: Atlas, 2016.

MAZZOLA, Marcelo. Impedimento de advogado deve se limitar à ação na qual ele é mediador. Revista Consultor Jurídico. 2015. Disponível em:

<http://www.conjur.com.br/2015-jul-11/marcelo-mazzola-impedimento-mediacao-

limitar-acao >. Acesso em: 23 fev. 2017.

MENDES, Gilmar Ferreira. Posse na Presidência do Supremo Tribunal Federal. Disponível em:

http://www.stf.jus.br/arquivo/cms/noticianoticiastt/anexo/possegm.pdf. Acessado em $\underline{02 / 03 / 2017}$.

ORLANDO, Fabíola. Relevantes Contribuições do Advogado para a Mediação. In: Manual de mediação de conflitos para advogados. Brasil: 2014.

PINHO, Débora. Novo CPC cria restrição para advogados na mediação. Revista Consultor Jurídico. 2015. Disponível em: <http://www.conjur.com.br/2015-mai21/debora-pinho-cpc-cria-restricao-advogados-mediacao>. Acesso em: 23 fev. 2017.

PINHO, Humberto Dalla Bernardina de. Mediação: a redescoberta de um velho aliado na solução de conflitos. In: PINHO,Humberto Dalla Bernardina de (Org.). Teoria geral da mediação à luz do projeto de Lei e do Direito Comparado. Rio de Janeiro: Lumen Juris, 2008.

RIBEIRO, Regina A.S.F. $O$ advogado na Conciliação e na Mediação. São Paulo: ESA.2016. Disponível em:

$<$ https://www.esaoabsp.edu.br/revista/edica013/data/document.pdf> Acesso em 03.fev.2017.

ROVER, Tadeu. Atuar como conciliador e mediador gera impedimentos para advogados. Revista consultor jurídico. 2015. Disponível em: $<$ http://www.conjur.com.br/2015-ago-04/atuar-conciliador-mediador-geraimpedimentos-advogados>. Acesso em: 23 fev. 2017. 


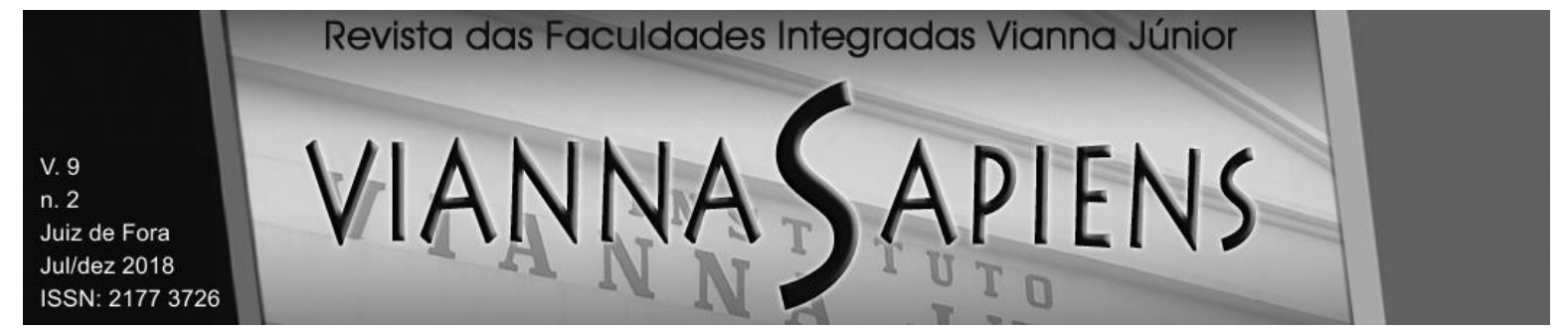

SALOMÃO,Luis Felipe. O marco regulatório para a mediação no Brasil. Em: <http://www.migalhas.com.br/dePeso/16,Ml221467,101048-

O+marco+regulatorio+para+a+mediacao+no+Brasil>. Acesso em: 04 março 2017.

SANTOS, Roberta Freitas Carvalho. Acesso à Justiça por meio da mediação de conflitos. Rio de Janeiro: EMERJ, 2012. Disponível:

<http://www.emerj.tjr.jus.br/paginas/trabalhos_conclusao/2semestre2012/trabalhos 22012/RobertaFreitasCarvalhoSantos.pdf>. Acesso em 02.Fev.2017.

SILVA, Carolina Marquez Castro; SCHABBEL, Corinna Margarete Charlotte.

Vantagens do método circular: narrativo aplicado à mediação empresarial. Goiás, 2017. Disponível: <http://www.idei.com.br/images/Artigos-Associados/Vantagens-dometodo-circular-narrativo-aplicado-a-mediacao-empresarial.pdf> Acesso em 15.Dez.2016.

TRIBUNAL DE JUSTIÇA DO ESTADO DE GOIAS. Teoria do Conflito. Goiana, 2015.Disponível:<http://www.tjgo.jus.br/conciliacao/pdf/CursosConciliacao/Teoria\%2 0do\%20conflito.pdf>. Acesso em 10.Fev.2017.

VASCONCELOS, Carlos Eduardo de. Principais características da mediação de conflitos. In: Manual de mediação de conflitos para advogados. Brasil: 2014.

WEBER, Lois J. Court-Referred ADR and the Lawyer-Mediator: In Service of Whom. SMU Law Review. V. 46. 1993. Disponível em:

$<$ http://scholar.smu.edu/cgi/viewcontent.cgi?article=2321\&context=smulr $>$. Acesso em: 28 fev. 2017.

WEISS, Raquel. Max Weber e o problema dos valores: as justificativas para a neutralidade axiológica. Rev. Sociol. Polit., Curitiba, v. 22, n. 49, p. 113137, Mar. 2014 . Disponível em: <http://www.scielo.br/scielo.php?script=sci_arttext\&pid=S010444782014000100007\&Ing=en\&nrm=iso>. Acesso em: 15 mai. 2017.

Recebido em 08/10/2018

Publicado em 21/12/2018 